\title{
Assessment of Corrosion and Scale forming Potential of Groundwater Resources: Case Study of Dire Dawa City, Ethiopia
}

\section{Girmaye Haile Gebremikael ${ }^{1 *}$ and Aman Hussien Dawod ${ }^{2}$}

${ }^{1}$ Process, Environmental Engineering and Energy Chair, Institute of Technology Dire Dawa University, P.O. Box 1362, Dire Dawa, Ethiopia (*grhaile@gmail.com).

${ }^{2}$ Geomatic and Geoinformatic Chair, Institute of Technology Dire Dawa University, P.O. Box 1362, Dire Dawa, Ethiopia.

\begin{abstract}
Almost $100 \%$ of the water supply of Dire Dawa City is from groundwater (including boreholes, dug wells, and springs). Recently, groundwater cause corrosion and scale problems to water distribution systems due to its content of dissolved ions that can cause public health and economic issues. The present paper investigates the corrosion and scale-forming potential of the groundwater in the city and visualize with mapping. Spectrophotometer, EDTA/Acid titration with calculation methods were used fors it water quality parameters analysis. GW Chart Calibration plot applied for the Piper diagram to categorizes the water types. Langelier saturation (LSI), Ryznar (RSI), aggressive (AI), Puckorius Scale (PSI), and Larson-Skold (LRI) indices were manipulated with Excel ${ }^{\circledR}$ and visualized their spatial distribution using ArcGIS $10^{\circledR}$. The mean values of LSI, RSI, PSI, AI, and LRI obtained were $0.29 \pm 0.28,6.4 \pm$ $0.5,5.10 \pm 0.48,12.20 \pm 0.24$, and $1.4 \pm 1.57$ respectively. LSI and RSI results indicate moderate to low scale-forming tendency of groundwater in most parts except the northeastern part with corrosive groundwater. Based on the AI value, the groundwater ranges low corrosion in almost all zones except the edge of the northeast and northwest region. PSI indicated the water tends to form salt-scale at a medium rate. The LSI results showed that chloride and sulphate are unlikely to interfere with the formation of protecting film except in northwestern and northeastern regions where localized corrosion might occur. In conclusion, in almost all distribution system of the city is affected by calcium carbonate scale formation. The groundwater in the northwest and northeast resulted in localized corrosion because of relatively high contents of chlorides and sulphates.
\end{abstract}

Keywords: Corrosion indices, Scale-forming, Water quality, GIS, Dire Dawa, Ethiopia.

\section{INTRODUCTION}

Ethiopia gets more than $80 \%$ of the drinking water supply from groundwater (Seifu et al., 2018). In the case of Dire Dawa, which is arid part of the country, there are no perennial rivers and streams. For the last 12 years, almost $100 \%$ of the water for the urban and rural population of Dire Dawa Administrative Council (DDAC) gets its water supply for domestic, industrial, and irrigation purposes exploited from boreholes, dug wells, and springs. Besides, the increasing water demands, there are other related issues from the source point to the distribution system from public health and economic aspects. This has not been considered a serious 
problem in Ethiopia until recent times (Seifu et al., 2018; Tamiru, 2006; Alemayehu, 1999; WWDSE, 2004 unpubl. data).

Naturally, water contains dissolved hardness-causing ions, iron, sodium, potassium chloride, sulphate, bicarbonate which cause corrosion and scale problems to the water distribution systems. Corrosion and scale add to the cost of water selling price because of high pump operation costs; replacement of failing pumps, pipes, and fittings; short life of water heaters, boilers, and cookers in-house and industries. Corrosion may cause the leaching of contaminants such as lead and copper into the water distribution network that would have hazardous concerns for community health (Mahmoud et al., 2012). It also rises customer complaints and loss of public trust due to water quality, low water pressure (Singley et al., 1984; Dobersek and Goricanec, 2007). There are a public drinking water distribution system and several private bottled water companies in Dire Dawa City which are facing problems related to corrosion and scale forming. According to the technical report (Antonaropoulos and Associates, 2017 unpubl. Data) on the incrustation problems of the city water distribution system stated an average of $2000 \mathrm{~m}$ long pipes damage each year. In the 2014-15 year annual reports of the city Water Supply and Sanitation Authority (DDWSSA), it was also presented that the pipe loss estimated $1 \%$ of the total distribution network length. The actual production capacity of the existing water sources is estimated at $415 \mathrm{l} / \mathrm{s}$, which corresponds to approximately $70 \%$ of their design yield (DDWSSA, 2015 unpubl. data).

It is crucial to monitor the effects of corrosion to deel with related concerns with evidence. The most widely used indirect monitoring methods are water analysis interpretation, consumer complaints and corrosion indices. Water stability indices easily analyze and predict corrosion or scale forming tendencies of water which are very handy in a corrosion control program (Singley et al., 1984; Alam and Sadiq, 1989).

Water corrosion or scale forming effect is related to its $\mathrm{pH}$, alkalinity, hardness, temperature, dissolved oxygen, total dissolved solids, and other factors (Salvato et al., 2003). These water stability indices combine the above-mentioned factors to indicate their contribution to corrosive or scale forming effects. Langelier Saturation (LSI), Ryznar stability (RSI), and aggressive (AI) indices are the most commonly used in the waterworks industry, which can indicate the tendency of water to be corrosive or not. They also predict water tendency to precipitate a corrosion protective salt coater. Scale forming occurs when thick layers of salt are deposited (Singley et al., 1984). 
Several researchers have investigated the water situation in terms of scale forming and corrosion. However, so far, almost no studies have been done on corrosion and scale forming potential of drinking water in Ethiopia and Dire Dawa. There was only one study (Gebremedhin et al., 2013) that estimated the corrosiveness of groundwater at different localities in Mekelle City using corrosion indices of Larson index and aggressive index. The results showed that groundwaters were corrosive than spring samples. Tavanpour and Noshadi (2016) showed that the mean value of Langelier, Ryznar, Puckorius, Larson, and Aggressive indices in the water distribution network of Shiraz city. The zones located in eastern, southeastern, and southern zones had scale-formation problems. Avaz-pur et al. (2008) studied Ilam City-Iran corrosion and scaling effect on water distribution system using Langelier saturation index, Ryznar stability index, and aggressive index. The indices indicated that water source three rivers were all corrosive. Aghapur et al. (2009) studied and indicated the water corrosion and scale-forming levels in distribution facilities of Urmia, Iran, that the corrosiveness was related to low hardness water. This resulted in a risk of heavy metals solution of lead, cadmium, copper, and zinc from pipelines. De Rosa (1993) studied scale formation in the drinking water distribution system of different regions of London, England. The results suggested a significant effect on the accumulation of scale particles. In addition to the lower pipes diameter became the more scale existed in the downstream main pipes of distribution networks.

GIS is useful for mapping the spatial distribution of different regions in water quality studies that several researchers have successfully utilized this tool (Assaf and Saadeh, 2009; Narany et al., 2014; Zarif et al., 2014). Zarif et al. (2014) using LSI, RSI index and GIS software studied the spatial variation of corrosion and scale forming potential of groundwater of 105 wells in the Dezfoul - Andimeshk Plain and the results showed increasing scale-forming tendency from north to south of plain. GIS-based assessment of corrosion and scale formation in Thanjavur, India by Kumar et al. (2014) indicated that most parts of the study area were occupied by moderate calcium and moderate to high corrosion, with more on the northern region of the area than the southern.

The purpose of the present study was to investigate the corrosion and scale forming potential of the groundwater source of Dire Dawa City using the water stability indices and visualize the geographical distribution on the studied area using GIS. 


\section{METHODOLOGY}

\subsection{Geographical description and data collection}

Dire Dawa City is located in the eastern part of Ethiopia taking the UTM coordinate system as a reference, the location of the city is between $804511 \mathrm{~m}$ to $816913 \mathrm{~m}$ west-east direction and $1059754 \mathrm{~m}$ to $1067650 \mathrm{~m}$ south-north direction as shown in Figure 1 . The City is located 515 $\mathrm{km}$ far from Addis Ababa, the capital city of Ethiopia, $311 \mathrm{~km}$ west of Djibouti port and $55 \mathrm{~km}$ to the north of the historic City of Harar. Dire Dawa City Administration (DDCA) consists of nine urban zones and other rural zones. To analyze the physicochemical parameters, groundwater samples of 15 boreholes were collected from Dire Dawa central area, Tome, Boren and Melka Jebdu as shown in figure 2. Additional secondary data of 67 sample points were obtained from the quality control laboratory of DDWSSA and Federal Water Works Design and Supervision (WWDSE) analyzed from 2004 to 2015 (WWDSE, 2004 unpubl. data; Eyilachew, 2010; MS consultancy, 2016 unpubl. data). For Secondary data, the accuracy was monitored with Ion Balance Error (IBE) calculation within a margin of $+/-5 \%$. The water resources were also located using Garmin Origon-550 GPS (Global Positioning System) in UTM coordinate system as shown in figure 1 and 2.

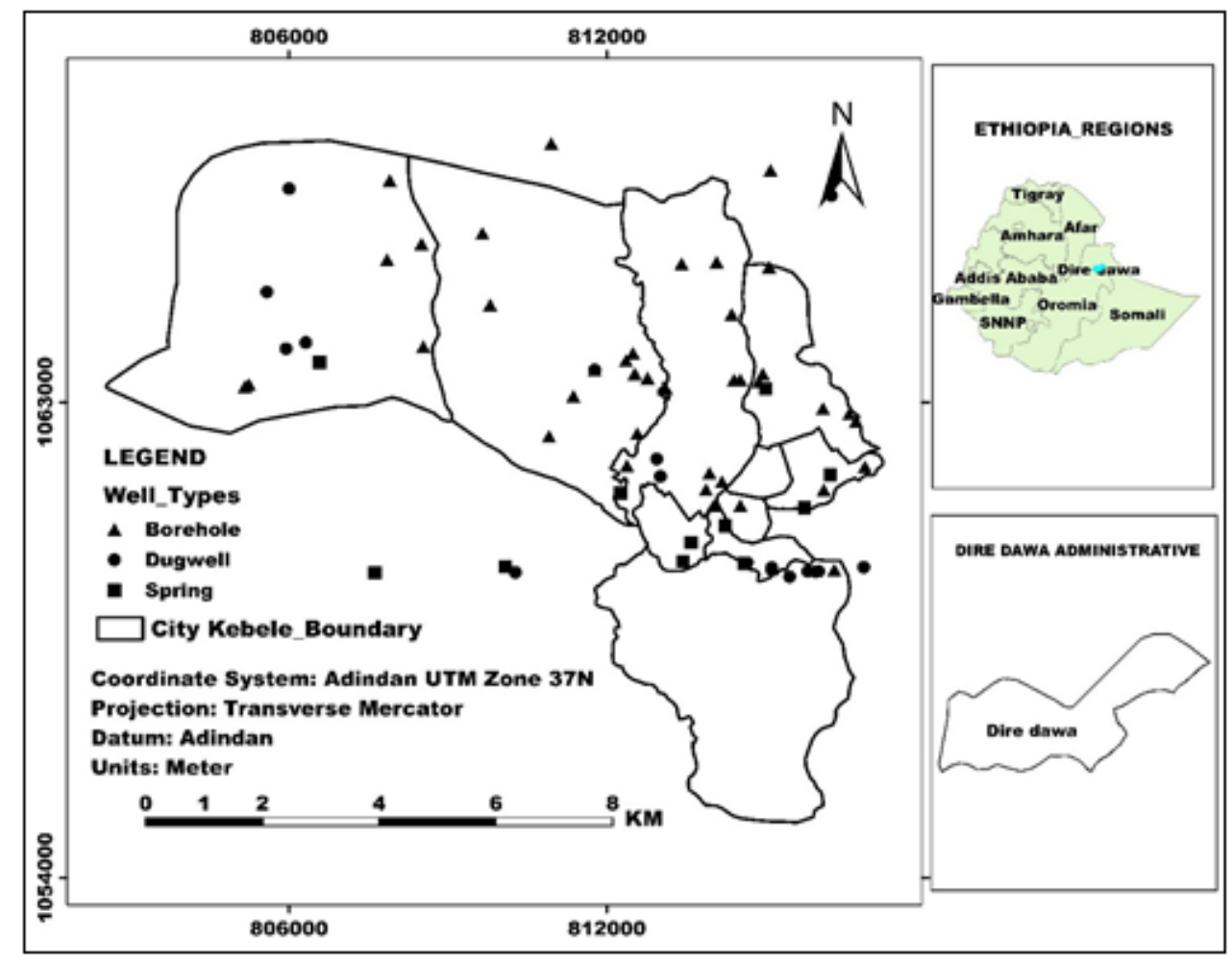

Figure 1. The geographical location of groundwater points, Dire Dawa City, Ethiopia. 


\subsection{Water Quality Parameters}

The samples were collected in pre-washed and rinsed polyethylene bottles. The temperature was measured on-site using portable meter. TDS, alkalinity, total hardness, cations (calcium and magnesium) were measured with acid and EDTA titrimetric, conductivity (EC meter), and calculation. Sulphate and chloride were measured using spectrophotometer at Dire Dawa University Water Sanitation office and Dire Dawa Water Supply and Sanitation Authority, Quality Control Laboratory. The hydrochemical facies of groundwater were understood by constructing Piper (1944) diagram with GW Chart Calibration plot (USGS, 2000).

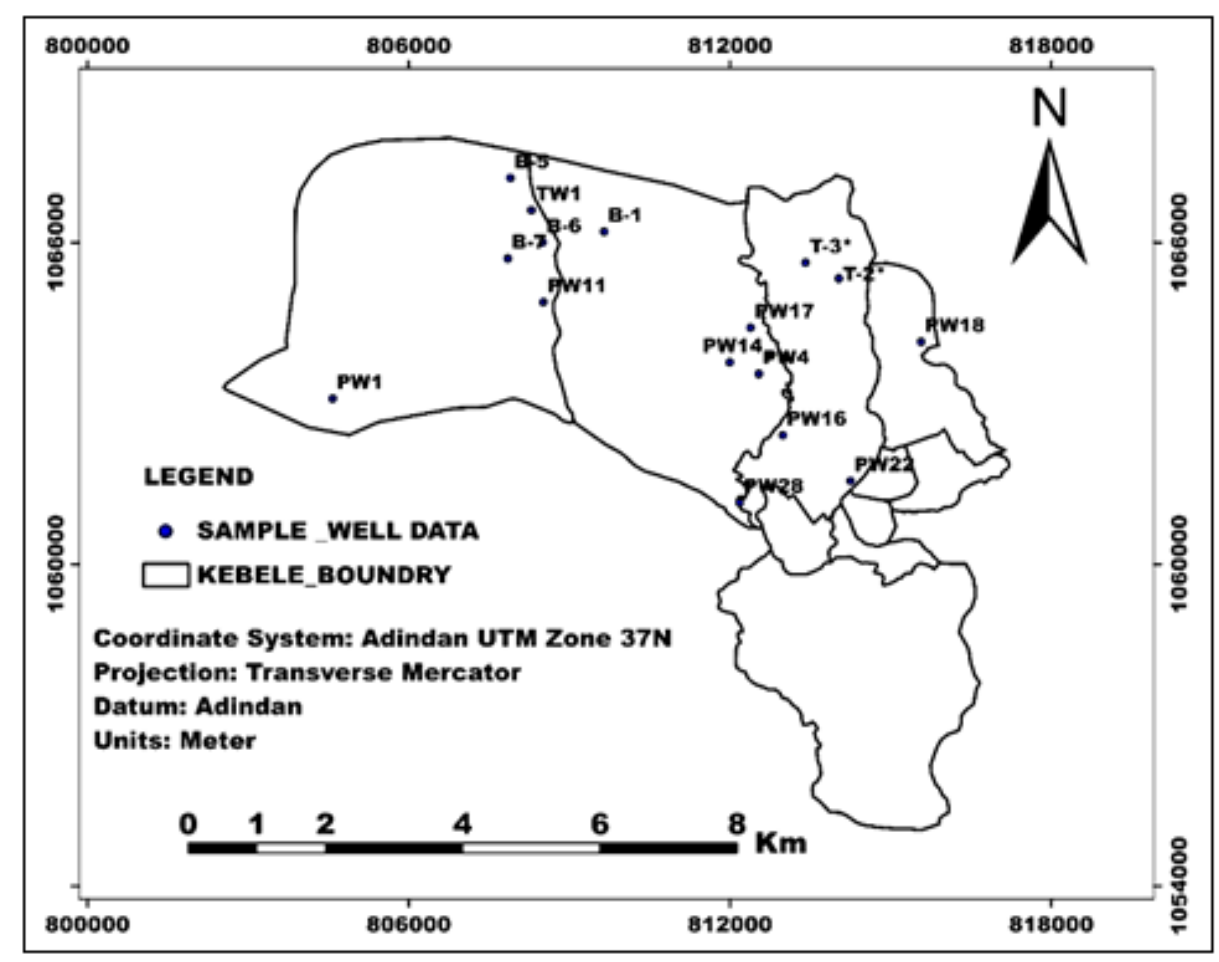

Figure 2. The spatial location of sampled water wells, Dire Dawa City, Ethiopia.

\subsection{Water Stability Indices}

With the help of the groundwater chemical and physical parameter data, the corrosion and scale forming indices of LSI, RSI, PSI, AI and LRI were calculated Excel ${ }^{\circledR}$ software for investigation of corrosion or water scale-forming. Summary of the most common indices interpretation and criteria for categorizing the stability of the water presented in table 1.

\subsubsection{Langelier Index (LSI)}

The Langelier index only shows the tendency of water to dissolve or form carbonate scale. it is only conducive to control the calcium carbonate content in systems (Langelier, 1936). 
LSI is expressed as

$\mathrm{LSI}=\mathrm{pH}-\mathrm{pHs}$

$$
\mathrm{pHs}=(9.3+(\log [\mathrm{TDS}]-1) / 10-(13.12 * \log (\mathrm{T}+273)+34.55)
$$

$-\left(\log \left(\mathrm{Ca}^{2+}\right)-0.4+\log (\right.$ Total Alkalinity $)$

T- temperature in ${ }^{\circ} \mathrm{C}$, TDS in $\mathrm{mg} / \mathrm{L}, \mathrm{Ca}^{2+}$ and Total Alkalinity in $\mathrm{mg} / \mathrm{L}$ as $\mathrm{CaCO}_{3}, \mathrm{pH}_{\mathrm{s}}$ is the $\mathrm{pH}$ in saturation state in calcite or calcium carbonate. The index could be efficient for systems at low water speed, TDS and temperature ranges (McNeill and Edwards, 2001; Singley et al., 1984).

\subsubsection{Ryznar Stability Index (RSI)}

While Ryznar index is experimental, it could only be used for (water inside the pipeline) with a velocity of about $0.6 \mathrm{~m} / \mathrm{sec}$. This index is often used in combination with the LSI to improve the accuracy of the prediction. Ryznar index is not suitable for the case of water saturation (Prisyazhniuk, 2007). RSI helps to monitor scale thickness.

RSI is calculated as follows.

$\mathrm{RSI}=2 \mathrm{pH}_{\mathrm{s}}-\mathrm{pH}$

\subsubsection{Aggressive Index (AI)}

The AI is a simplified form of the Langelier index and only approximates the solubility of $\mathrm{CaCO}_{3}$ and water acidity but the corrosion effect.

The index is calculated as

$\mathrm{AI}=\mathrm{pH}+\log [(\mathrm{A})(\mathrm{HC})]$

A is Total Alkalinity and $\mathrm{HC}$ is Calcium hardness in $\mathrm{mg} / \mathrm{L}$ as $\mathrm{CaCO}_{3}$

However, it can be a useful tool in selecting materials like asbestos-cement lining pipelines or treatment options for corrosion control (Von Huben, 1995).

\subsubsection{Larson-Skold Index (LRI)}

This index was developed by Larson and Skold (1958) for examining the extent of corrosion based upon the aggressiveness of chloride and sulphate in water and alkalinity as aggression reducer which is exposed to steel pipelines with light carbonic structure and cast-iron pipes (Singley et al., 1984; Singh and Chakradhar, 1998).

Larson-skold index is calculated as:

$\mathrm{LSI}=\frac{\mathrm{C}_{\mathrm{cl}^{-}}+\mathrm{C}_{\mathrm{SO}^{-2}}}{\mathrm{C}_{\mathrm{HCO}_{3}^{-1}+\mathrm{C}_{\mathrm{CO}_{3}^{-2}}}}$

(all ionic concentrations are expressed in $\mathrm{mg} / \mathrm{L}$ as $\mathrm{CaCO}_{3}$ )

(c) CNCS, Mekelle University 


\subsubsection{The Pockurius Scale forming Index (PSI)}

PSI is based on buffer capacity. It is explanatory of the maximum quantity of scale that may bring in water. In this index, the use of equilibrium $\mathrm{pH}\left(\mathrm{pH}_{\mathrm{eq}}\right)$ is more than actual $\mathrm{pH}$.

To calculate Pockurius index

$\mathrm{PSI}=2 \mathrm{pH}_{\mathrm{s}}-\mathrm{pH}_{\mathrm{eq}}$

$\mathrm{pH}_{\mathrm{eq}}=1.465 \log ($ Total Alkalinity $)+4.54$.

A is Total Alkalinity in $\mathrm{mg} / \mathrm{L}$ as $\mathrm{CaCO}_{3}$

PSI is a practical index for scale forming. A high salt saturation level is observed if the water contents of high calcium \& magnesium ion but less alkalinity and buffering capacity. The number resulting from this index is similar to RSI (Singley et al., 1984; Puckorius and Brooke, 1991).

Table 1. Summary of Corrosion and Scaling Index (Abbasnia et al., 2018; Acharya et al., 2018; Hadi, 2010).

\begin{tabular}{|c|c|c|}
\hline & Index value & Interpretation \\
\hline \multirow{4}{*}{$\begin{array}{l}\text { Langlier } \\
\text { Saturation Index }\end{array}$} & $-4<\mathrm{LSI}<-2$ & Mild Corrosion \\
\hline & $-1<$ LSI $<0$ & Low Corrosion \\
\hline & $\mathrm{LSI}=0$ & Balanced \\
\hline & $0<\mathrm{LSI}<2$ & Low to Moderate Scale-forming \\
\hline \multirow{4}{*}{$\begin{array}{l}\text { Ryzan } \\
\text { Stability Index }\end{array}$} & $\mathrm{RS}<5.5$ & Highly scale-forming \\
\hline & $5.5<\mathrm{RS}<6.2$ & Relatively scale-forming and corrosive \\
\hline & $6.2<\mathrm{RS}<6.8$ & Balanced \\
\hline & $\mathrm{RS}>6.8$ & Corrosive \\
\hline \multirow{3}{*}{$\begin{array}{l}\text { Larson Skold } \\
\text { Index }\end{array}$} & $\mathrm{LRI}<0.8$ & $\begin{array}{l}\text { Formation of protective media without the } \\
\text { mediation of } \mathrm{Cl}^{-} \& \mathrm{SO}_{4}^{-2} \text { ions }\end{array}$ \\
\hline & $0.8<\mathrm{LRI}<1.2$ & $\begin{array}{l}\text { Formation of scale with the mediation of } \mathrm{Cl}^{-} \& \\
\mathrm{SO}_{4}^{-2} \text { (corrosion rates more than expected) }\end{array}$ \\
\hline & LRI> 1.2 & High rates of localized corrosion \\
\hline \multirow[t]{3}{*}{ Aggressive Index } & $\mathrm{AI}<10$ & High water corrosion \\
\hline & $\mathrm{AI}=10-12$ & Moderate water corrosion \\
\hline & $\mathrm{AI}>12$ & Lack of water corrosion \\
\hline \multirow{3}{*}{$\begin{array}{l}\text { Pockurius } \\
\text { Saturation Index }\end{array}$} & PSI $<5$ & The water intended to be scale forming \\
\hline & $5<$ PSI $<7$ & Relatively scale-forming \\
\hline & PSI $>7$ & water tend to dissolve if exist any scale \\
\hline
\end{tabular}

\subsection{Spatial distribution analysis of the indices}

The city boundary shapefile data were taken from the city administration. The collected spatial data of bore wells were downloaded with DNR Garmin software in CSV file format and match 
with the calculated index values. Finally, the geocoded (address matching with other tabular data) was brought into ArcGIS $10.3^{\circledR}$ software for spatial analysis. Among different spatial analysis tool, interpolation technique which has been used for analyzing the geocoded index of each point. Among different interpolation techniques, the researcher most used IDW and kriging in corrosion and scale forming studies (Webster and Oliver, 2007; Kumar and Gorail, 2013; Zarif et al., 2014).

\section{RESULT AND DISCUSSION}

According to Habteab and Jiri (2018); Eyilachew (2010); Minalah (2007); Tamiru (2006); WWDSE (2004); and Seife Michael (1982), the city is covered by limestone, sandstone, shale, and chalk of Mesozoic age.

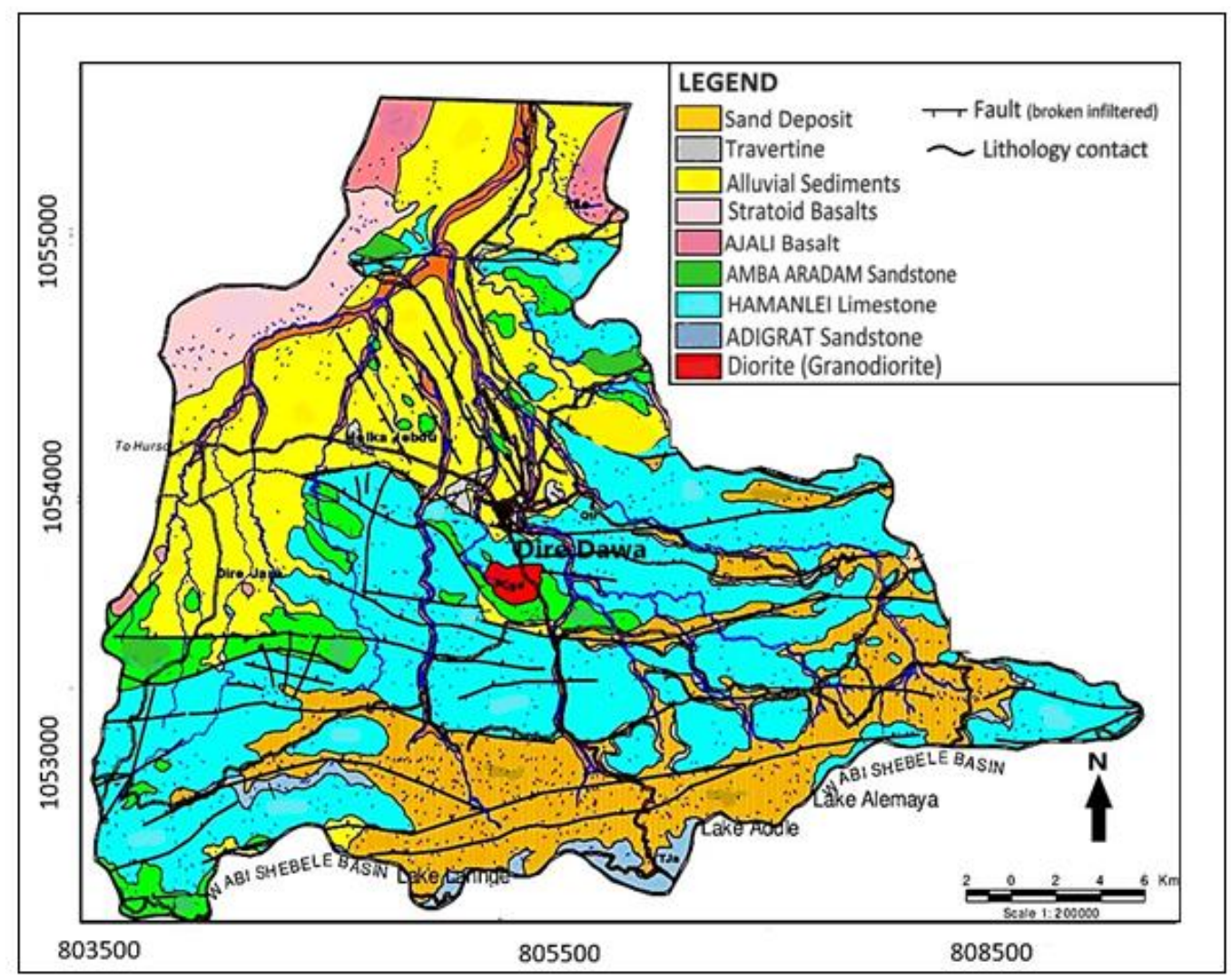

Figure 3. Geological Map of Dire Dawa Basin (WWDSE, 2004; Eyilachew, 2010).

The western part, the upstream, is dominated by sandstone and hamanlei limestone units are the most productive aquifers in the area. Alluvial sediment deposits dominantly cover the east, downstream area, as it unconfined unit composed of clay, silt, sand, gravel and rock fragments in the groundwater basin as shown in figure 3. 
The Piper graph (Fig 4) showed that most of the samples related to the high concentration of $\mathrm{Ca}\left(\mathrm{HCO}_{3}\right)_{2}$ and $\mathrm{CaMg}\left(\mathrm{CO}_{3}\right)_{2}$ the significant amount of $\mathrm{CaSO}_{4}$. The groundwater of $\mathrm{CaHCO}_{3}, \mathrm{Ca}-\mathrm{HCO}_{3}-\mathrm{SO}_{4}$ and $\mathrm{CaMg}\left(\mathrm{CO}_{3}\right)_{2}$ dominated water types in boreholes and dug well. As observed by Habteab and Jiri (2018), the $\mathrm{Ca}-\mathrm{Mg}-\mathrm{HCO}_{3}$ dominant groundwater and springs the southern, and western parts of the study area whereas $\mathrm{Ca}-\mathrm{HCO}_{3}-$ $\mathrm{SO}_{4}$ in the central part of the city due to domestic and industrial waste (chloride and sulphate dominant).

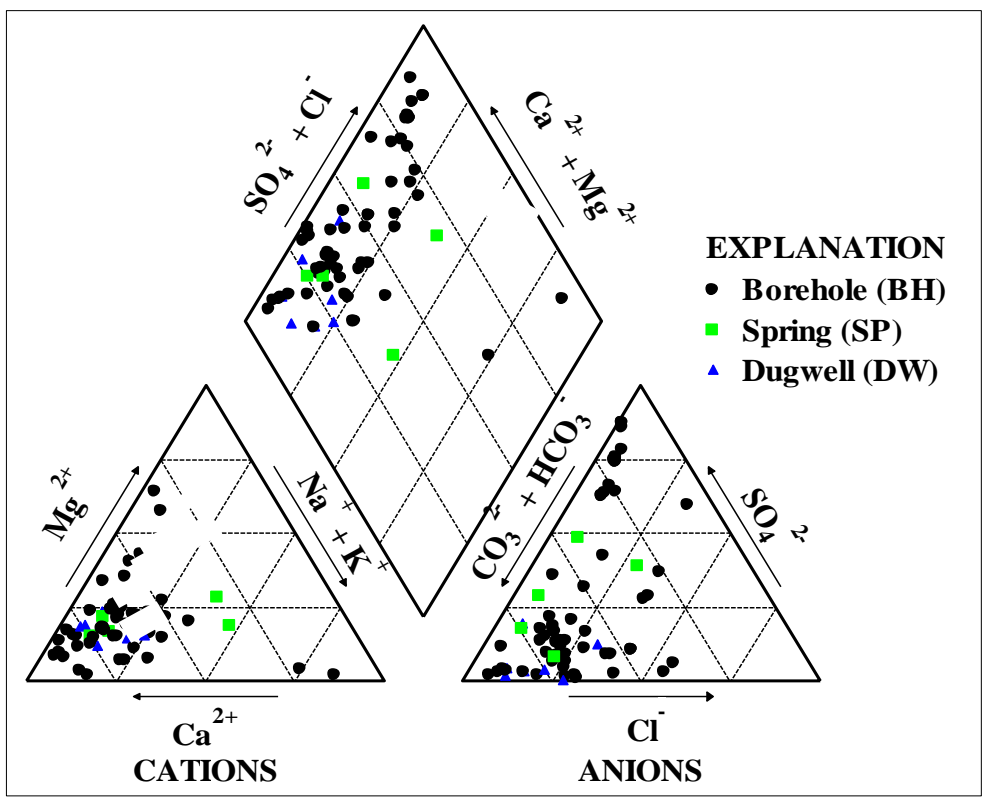

Figure 4. Piper graph of groundwater source of Dire Dawa City.

On the other hand, springs in Melka Jebdu possess $\mathrm{Ca}-\mathrm{Mg}-\mathrm{Na}-\mathrm{HCO}_{3}$ dominant water types. The sodium originated due to possibly halite from lake connections to Wabi ShebeleAwash River basin and flow towards Dire Dawa plain area (Habteab and Jiri, 2018; Eyilachew, 2010). According to reports and studies, high total dissolved solids from excess calcium and magnesium concentrations, and concentrations sulphates and bicarbonate existed in the groundwater sources (Habteab and Jiri, 2018; Antonaropoulos and Associates, 2017 unpubl. data; DDWSSA, 2015 unpubl. Data; WWDSE 2004).

The high concentration of bicarbonate, sulphate, and chloride causes the incrustation and corrosion action (Sawyer and McCarty, 1967; Aiman and Enab, 2007; Anon, 1983). The values of the groundwater physical and chemical parameters of sample points are presented in appendix 1,2 and 3.

\subsection{Physical and Chemical parameters}




\subsubsection{Total Dissolved Solids}

Total dissolved solids (TDS) is mainly contents of inorganic salts and dissolved organic matter in groundwater (WHO, 2003). A TDS increases conductivity, as result, it facilitates corrosion electrochemical reaction. TDS may also affect the formation of protective films since it was related to the excess calcium-based bicarbonate, sulphate, and chloride. High TDS (>500) result in excessive scaling in water pipes, water heaters, boilers, and household appliances (WHO, 2003). The TDS higher than the desirable level (>500) were observed in boreholes and springs (Habteab and Jiri, 2018; Antonaropoulos, 2017 unpubl. data; Eyilachew, 2010; WWDSE, 2004).

\subsubsection{Acidity (pH of water)}

Water with $\mathrm{pH}>9$ tends to reduce corrosion and also tends to stabilize around $\mathrm{pH}=6.5$ (Health Canada, 2009). The mean values of wells and springs were found to be between 6.7 and 7.2 that were stable enough.

\subsubsection{Alkalinity}

Alkalinity serves to control the buffer intensity of most water systems. It provides a stable $\mathrm{pH}$, as a result, prevents corrosion of lead, copper, and cement-based linings pipes. The mean values of alkalinity were between 248 to $440 \mathrm{mg} / \mathrm{L}$. If the alkalinity level is higher than $100 \mathrm{mg} / \mathrm{L}$, leads to scale-forming on a pipe wall. Also, the high alkalinity avoids point corrosion which is caused by rapid $\mathrm{pH}$ change of the water. The fact that bicarbonate more than $400 \mathrm{mg} / \mathrm{l}$ causes incrustation problems (Anon, 1983) that bicarbonate of the PW17, PW18, PW22, T-2, T-3 recorded more than the limit $(<400 \mathrm{mg} / \mathrm{l})$. A total of $66 \%$ of the samples, more than the limits (<400 mg/l), were all boreholes and dug wells. The groundwater of $\mathrm{pH}$ less than 8 , had no concentration of carbonate $\left(\mathrm{CO}_{3}^{-2}\right)$ so it was bicarbonate dominant (McDonald, 2006).

\subsubsection{Hardness (Calcium and Magnesium)}

Calcium and Magnesium are responsible for the hardness, originate from limestone and dolomite respectively. The values of calcium (157.6 to $568 \mathrm{mg} / \mathrm{L})$ and magnesium ion (8.9 to $144 \mathrm{mg} / \mathrm{L}$ ) were relatively high in both spring and wells that all samples were categorized as hard water. The high hardness contributed to the formation of dominated with calcium carbonate protective layer and inhibits the corrosion of pipes. The excessive scale-formation in pipes is mostly responsible for the frequent blockage of water supply systems (WHO, 2011). Hardness also causes high soap consumption, and the deterioration of fabrics at values above $200 \mathrm{mg} / \mathrm{L}$ and high alkalinity (John et al., 2012). 


\subsubsection{Sulphate and Chloride}

Sulphate is a strong corrosion catalyst implicated in the pitting corrosion of copper and lead (Health Canada 2009; Ferguson et al., 1996; Berghult et al., 1999). The mean sulphate values were between 68.8 to $1809.1 \mathrm{mg} / \mathrm{l}$. The desirable sulphate ion is limited below $250 \mathrm{mg} / \mathrm{L}$ (Anon, 1983) to avoid incrustation in low $\mathrm{pH}$. Only $35.4 \%$ of the samples were above the limit of calcium bicarbonate and sulphate with the highest value of borehole PW17, PW18, PW22, and Tome wells T-1 and T3 in Police Meret and Legahare which are populated and oldest settlement of the city. Chloride is the most active and corrosive ion (Jones, 1996). 87.7\% of the wells and springs samples were within the limit $(200 \mathrm{mg} / \mathrm{l})$. The aggressiveness of water containing high alkalinity, bicarbonate and sulphate resulted in lower corrosion since the larger percentage of the current carried by $\mathrm{SO}_{4}^{2-}$ or $\mathrm{HCO}_{3}^{-}$competing with chloride. A chloride to sulphate mass ratio (CSMR) less than 0.7, is desirable in which the corrosion rate is low (EPA, 2016; Reiber et al., 1997; Nguyen et al., 2011). Value of CSMR of sample TW1, PW17, PW18, PW22, T-3 and T-2 were below 0.7 that the groundwater was less corrosive to galvanized metals. On the contrary, $76 \%$ of the well CSMR values were more the limit (>0.7) that able galvanized corrosion.

\subsection{Corrosion and Scale-forming Indices}

Since a corrosive or scale-forming tendency of water is a complicated phenomenon, many attempts have been made to develop an index and several of the indices have been useful for prediction purposes (McNeill and Edwards, 2001). There is no single corrosion index applicable to all materials. Corrosion indices, particularly those related to calcium carbonate saturation, have given mixed results. The mean values of LSI, RSI, PSI, LRI and AI obtained as $0.29 \pm 0.28,6.4 \pm 0.5,5.10 \pm 0.48,2.06 \pm 0.25$ and $12.20 \pm 0.24$ respectively. The corrosion and scaling forming indices of the sample points were displayed in tables 2,3 and 4 above. Mapping the spatial distribution of the corrosion indices in the study area was best interpolated with kriging method. To validate the map, the real indices values and the predicted ones was cross-checked.

\subsubsection{Langelier and Ryznar Indices}

The Langelier index values in all zones ranged from -0.37 to 0.98 . According to LSI, all the samples were above zero with a minimum value related to point PW 18. Besides, majority of water sources $(95 \%)$ were supersaturated which could form scale at moderate rate and consequently damaged drinking and other water-consuming and distribution systems. In this regard, as per figures 5 and 6 , the groundwater that tendency to form a scale located in most 
parts of the study area except the north-west and north-east part the city with corrosive groundwater points. While the highest values obtained (most scale-forming) were related to the north-center. The Ryznar index values were in the range of 5.60 to 7.29 while among the samples the maximum value was related Boren borehole B-1, B-5 and B-6 as displayed in appendix tables.

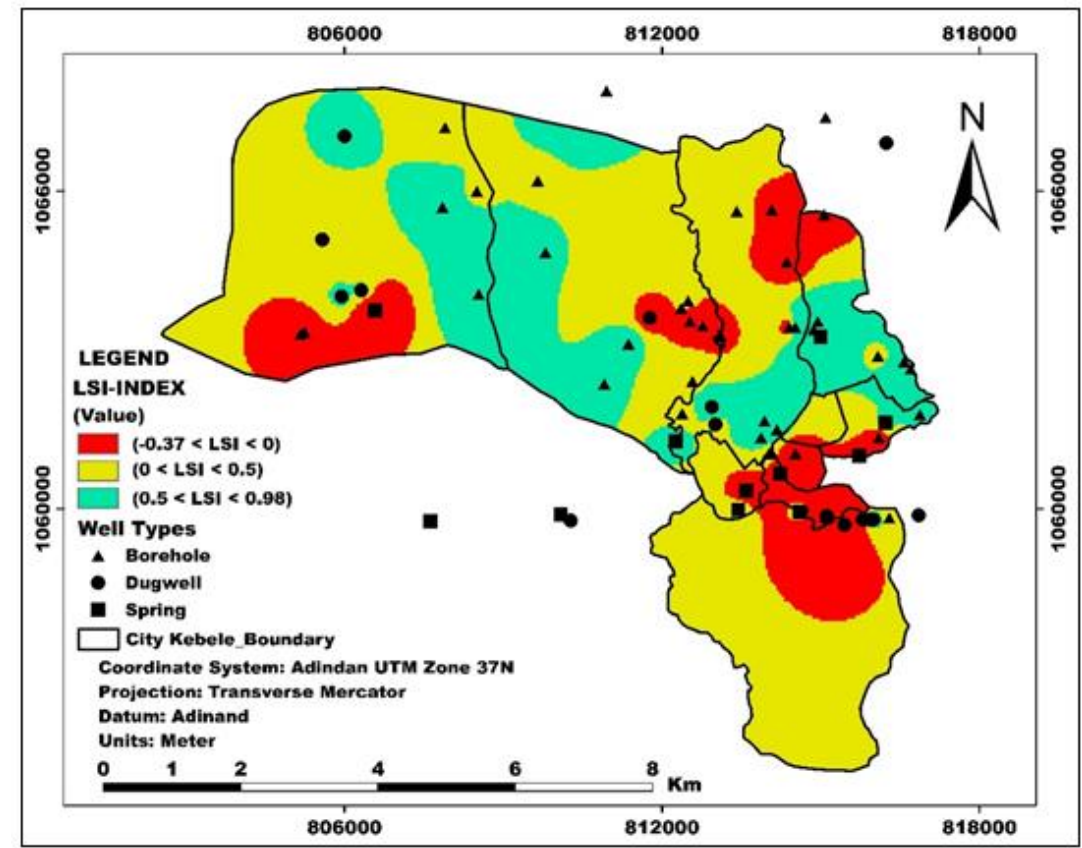

Figure 5. Maps of spatial changes of Langelier Saturation Index of Dire Dawa city.

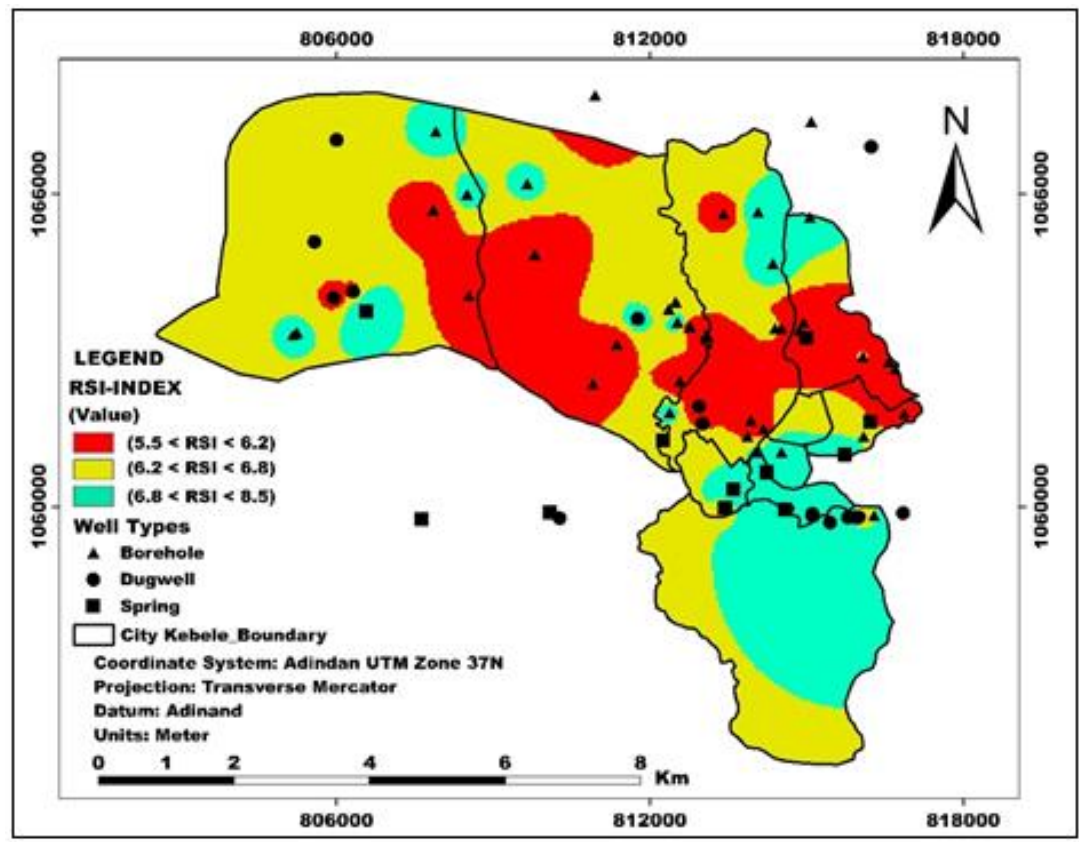

Figure 6. Maps of spatial changes of Ryznar Index of Dire Dawa city.

(C) CNCS, Mekelle University 
More than half of the boreholes and dug wells (59.7\%) had a scaling tendency on pipeline and water operating equipment and the other $20.8 \%$ of groundwater source points were balanced. However, the other $19.5 \%$ of the groundwater points were corrosive to metals and deteriorated effects on cement-lined and plastic pipes. The Ryznar index, in figure 6, showed relative scale-forming and saturated north part. However, the edge south and northwest part groundwater had shown corrosion tendency. Langelier index, on one hand, is preferably used for still waters and is used for control of bicarbonate scale formation. In this case, TDS was calcium bicarbonate dominant groundwater. On the other hand, the Ryznar index may be used with moderate to hard water but does not apply to soft or saline waters.

\subsubsection{Aggressive Index}

The aggressive index mean values in all zones ranged from 11.59 to 12.93 . Almost all (87\%) data were nonaggressive (AI greater or equal to 12) groundwater. The other $13 \%$ exhibited a corrosion rate ranged low to moderate. The wells with minimum AI values were located in the northeastern edge and the maximum values in central and northwestern. AI does not incorporate temperature or TDS effects. The groundwater ranged from low to medium corrosion and its effect is only applicable to asbestos-cement pipelines.

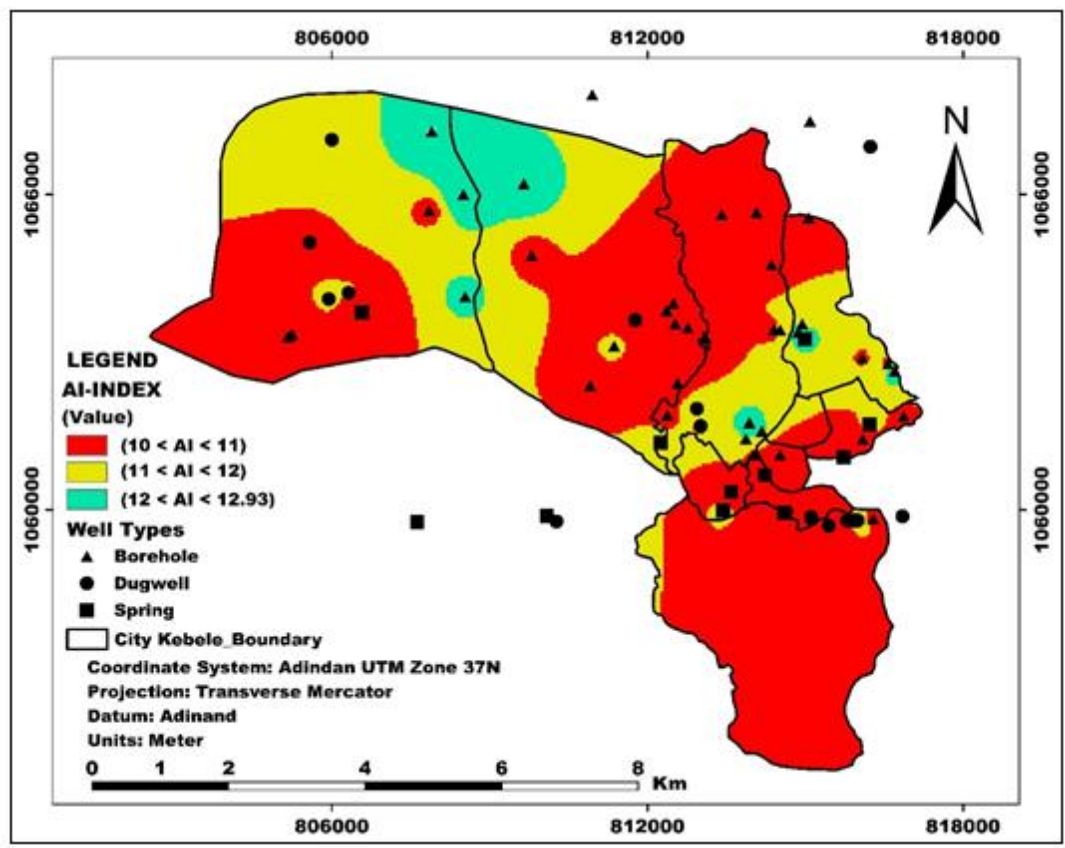

Figure 7. Maps of spatial changes of Aggressive Index of Dire Dawa City.

\subsubsection{Puckorius Scale forming Index}

The mean values of the index in all zones ranged from 4.23 to 5.87. Based on the results, the water tended to be scale-forming at moderate in most of the regions especially northwestern (c) CNCS, Mekelle University 
and central parts. The groundwater has high calcium concentration and high alkalinity consequently possess high buffering capacity. The calcium precipitated from the oversaturation over the less of $\mathrm{pH}$ change. The high values PSI in the southern and northeast edges indicated that groundwater was from less scale forming and tended to dissolve any existing scales.

\subsubsection{Larson-Skold Index}

The groundwater that has high calcium and alkalinity (bicarbonate), possesses high buffering capacity (Sajil Kumar, 2019). So the groundwater aggressiveness containing sufficient buffering capacity and alkalinity is due to the increase in chloride and sulphate (Larson and Skold, 1958).

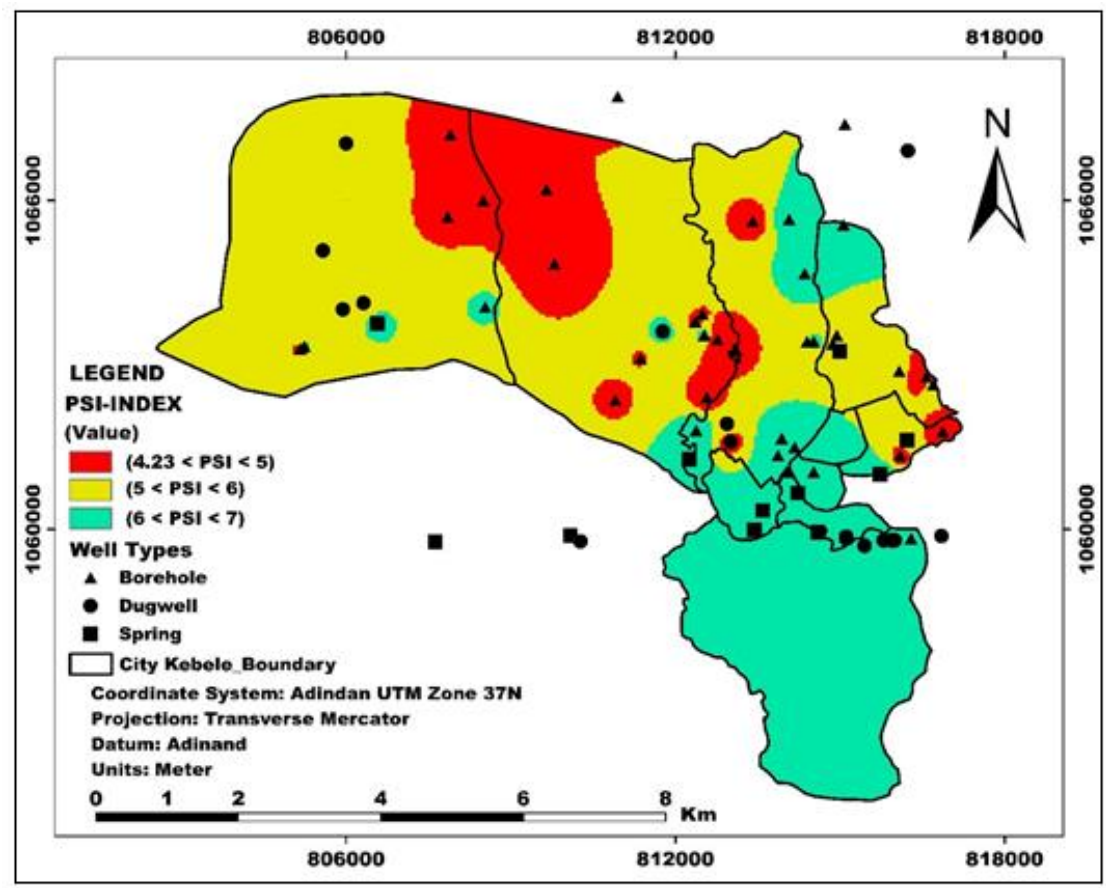

Figure 8. Maps of spatial changes of Pockurius Scaling Index of Dire Dawa City.

The Larson index values in all zones ranged from 0.09 to 6.03. Both the minimum value of the index (i.e. most scale-forming) and the maximum value (i.e. localize corrosion) were related to wells located in northwestern. This index is associated with corrosion of steel, ironcast pipes and also leaching lead, copper, tin into the water. Chloride and sulphate are unlikely to interfere with the formation of protecting film in most of the city except northwestern and northeastern where corrosion would be expected. Tome mountain well field in northeast exhibited where localized corrosion effect existed. The geology also confirms present of marine sediment rich in sulphate (MS consultancy, 2016 unpubl. data). Melka Jebdu well field in 
northwest is populated and has poor municipal northwest is populated and has poor municipal waste management. Animal and human waste are also the main source of sulphate and chlorine (Eyilachew, 2010).

In summation, the calcium and magnesium, bicarbonate and sulphate dominant salt in groundwater caused a moderate scale as indicated by LSI, RSI and PSI. On the other hand, the groundwater was also the source of low corrosion problems as indicated by AI and LRI mainly due to high TDS and warm temperature.

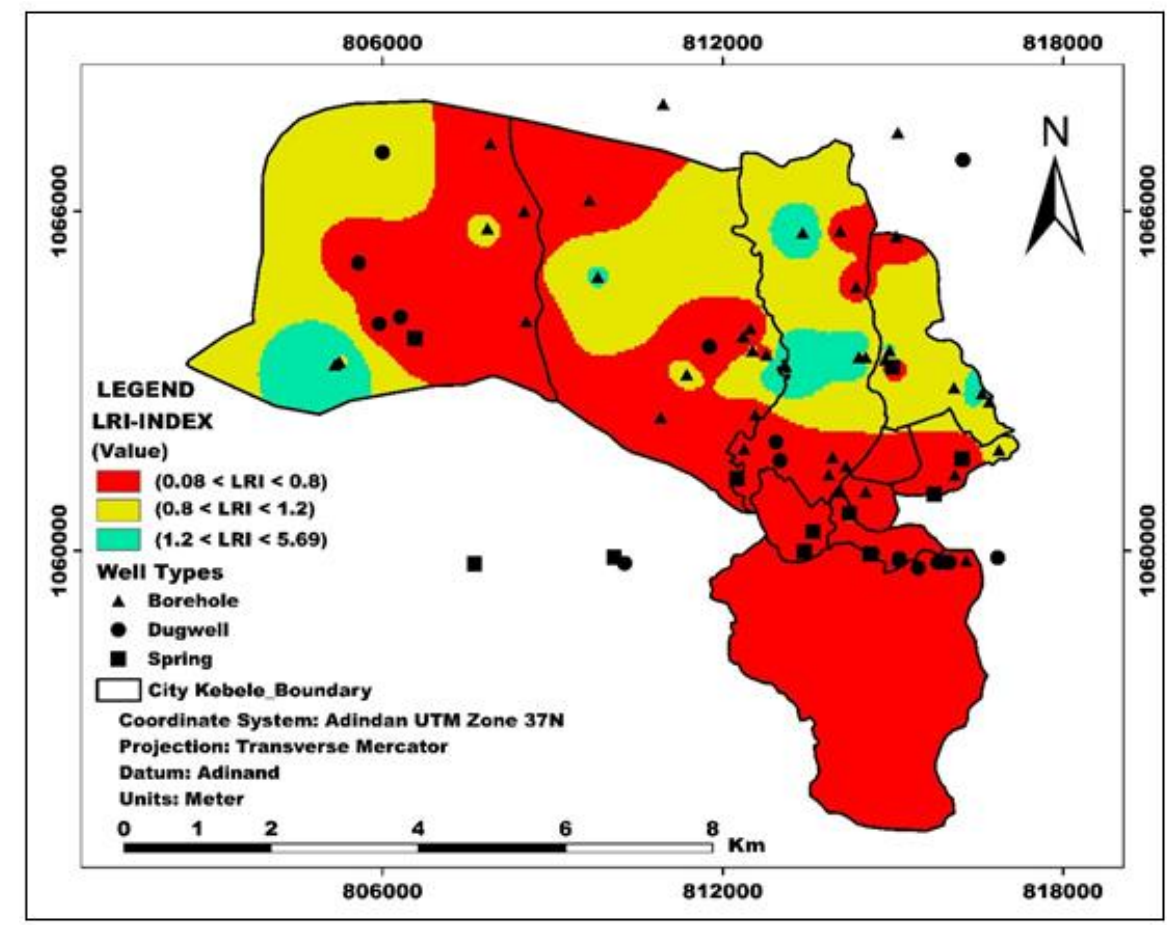

Figure 9. Maps of spatial changes of Larson-Skold Index of Dire Dawa City.

In northeastern and northwestern, the groundwater contained significant amount of chloride and sulphate that dangerous pitting corrosion might exist which is fast and localize according to Larson and Skold (1958). Geographically, the corrosion tendency of groundwater in Dire Dawa City increases from south to north direction. The scaling problem was more aggressive at the center of the city, where most of the groundwater sources exist.

\section{CONCLUSIONS}

Assessment of the corrosion and scale forming tendency of the groundwater in Dire Dawa City was performed using five water stability indices. These indices prove very helpful to the city public drinking water distribution systems and other industrial water utility supervisors, field engineers, and policymakers in monitoring and manage water corrosion and scale-forming (c) CNCS, Mekelle University 
effects. The groundwater stability was mainly influenced by parameters of TDS, total hardness, alkalinity, calcium, magnesium, sulphate and chloride. The piper diagram of the groundwater samples revealed that the samples fall under $\mathrm{Ca}-\mathrm{Mg}-\mathrm{HCO}_{3}, \mathrm{Ca}-\mathrm{Mg}-\mathrm{HCO}_{3}-\mathrm{SO}_{4}$ and $\mathrm{Ca}-\mathrm{Mg}-$ $\mathrm{HCO}_{3}-\mathrm{Cl}$ type water. Finally, according to the indices used in the study, it can be concluded that groundwater sources of Dire Dawa City behave from moderate to low scale. The groundwater contains hardness of mainly calcium, carbonate and sulphate from the natural occurrence. Tome (northeast region) and Melka Jebdu (northwestern region) are highly inhabited and old settlements that the groundwater had localized corrosion tendency due to relatively high content of chloride and sulphate. A recent over-pumping of the drinking water also caused a sudden drop in the groundwater level. Consequently, this increased salinity of the water exceeds limits and also led to carbonates and sulphate precipitation in pipes and water supply systems. This increasing trend requires more protection of the water resources and implementation of water treatment systems.

\section{ACKNOWLEDGMENTS}

The authors would like to acknowledge Dire Dawa Water Supply Authority for their support on laboratory utilization, fieldwork and documents. Dire Dawa University, Engineering Unit (Water Sanitation Facility) laboratory utilization and Dire Dawa Institute of Technology for financial support. The authors wish to thank anonymous reviewers for their valuable suggestions and comments.

\section{CONFLICT OF INTEREST}

There is no conflict of interests.

\section{REFERENCE}

Abbasnia, A., Alimohammadi, M., Mahvi, A.H., Nabizadeh, R., Yousefi, M., Mohammadi, A.A., Pasalari, H \& Mirzabeigi, M. 2018. Data in Brief Assessment of groundwater quality and evaluation of scaling and corrosiveness potential of drinking water samples in villages of Chabahr city, Iran. Data in Brief, 16: 182-192.

Acharya, S., Sharma, S. K \& Khandegar, V. 2018. Data in Brief Assessment and hydrogeochemical characterization for evaluation of corrosion and scaling potential of groundwater in South West Delhi, India. Data in Brief, 16: 182-192. 
Aghapur, A., Mohamadi, A \& Boini, A. 2009. The study of corrosion and scale-formation of output water of no.1 treatment center of Urmia City. In: National Conference of Environmental Safety, 12:16.

Aiman, E. A \& Enab, M. A. 2007. Assessment of tap water resources quality and its potential of scale formation and corrosivity in Tafila Province, South Jordan. Desalination, 206: 322-332.

Alam, I.A. \& Sadiq, M. 1989. Metal contamination of drinking water from corrosion of distribution pipes. Environmental Pollution, 57(2): 167-178.

Alemayehu, T. 1999. Pollution of the hydrogeologic system of Dire Dawa groundwater basin. In: Pickford, J.(ed). Integrated development of water supply and sanitation: Proceeding of the $25^{\text {th }}$ wedc International Conference, 25: 200-202.

Anon. 1983. Groundwater and Wells. $1^{\text {st }}$ edition, Johnson Division, Jain brothers, 450p.

Assaf, H \& Saadeh, M. 2009. Geostatistical assessment of groundwater nitrate contamination with reflection on DRASTIC vulnerability assessment: the case of the upper Litani Basin, Lebanon. Water Resource Management, 23(4): 775-796.

Avaz-pur, M., Gholami, M \& Ali, R. 2008. The study of corrosion and scale-formation potential or drinking water resources of Ilam City, Zahedan, Sistan and Baluchesta. In: National Conference of Environmental Health, 11: 10-15.

Berghult, B., Hedberg, T \& Broo, A.E. 1999. Drinking water distribution: corrosion control in Swedish municipalities. Journal Water Supply Research Technology, 48(2): 44-52.

De Rosa, S. 1993. Loose deposits in water mains. Report DoE 3118-/2. Department of the Environment, London.

Dobersek, D \& Goricanec, D. 2007. Influence of water scale on thermal flow losses of domestic appliances. International Journal of Mathematical Models and Methods in Applied Sciences, 1(2): 55-61.

EPA. 2016. Optimal Corrosion Control Treatment Evaluation Technical Recommendations for Primacy Agencies and Public Water System. EPA 816-B-16-003, $6^{\text {th }}$ ed., Office of Water, Environmental protection Agency.

Eyilachew, Y. A. 2010. Anthropogenic Impacts on Groundwater Resources in the urban Environment of Dire Dawa, Ethiopia. Masteroppgave, University of Oslo, Oslo. (Available online at https://www.duo.uio.no/handle/10852/12524?show=full) 
Ferguson, J.F., Franqué, O.V \& Schock, M.R. 1996 Corrosion of copper in potable water systems. In: Internal corrosion of water distribution systems, $2^{\text {nd }}$ edition, American Water Works Association, Denver, CO, pp. 231-268.

Gebremedhin, B., Tesfahunegn, A \& Solomon, G. 2013. Implications of groundwater quality to corrosion problem and urban planning in Mekelle area, Northern Ethiopia. Momona Ethiopian Journal of Science, 5(1): 51-70.

Habteab, Z \& Jiri, S. 2018. Hydrogeological and Hydrochemical Maps of Dire Dawa NC 37 12 Sheet, Explanatory Notes. Geological Survey of Ethiopia, Groundwater Resources Assessment, Addis Ababa.

Hadi, M. 2010. Development of a software for calculation of eight important water corrosion indices. In: National conference on environmental health, 12.

Health Canada. 2009. Guidance on Controlling Corrosion in Drinking Water Distribution Systems. Water, Air and Climate Change Bureau, Health Canada, Ontario,

John C. C., Rhodes T.R, David W. H, Kerry J. H \& George T. 2012. MWH's Water Treatment Principles and Design. $3^{\text {rd }}$ edition, John Wiley \& Sons, Inc.

Jones, D. A. 1996. Galvanic corrosion. In: Principles and Prevention of Corrosion. Prentice Hall, Upper Saddle River, NJ.

Kumar, K. R., Das, A., Goel, M., Nagarajan, R., Env, N \& Tech, P. 2014. Evaluation of Effect of Calcium on Scale Formation and Corrossivity of Groundwaterusing GIS. Nature Environment and Pollution Technology, An International Quarterly Scientific Journal,13 (1): 101-106

Kumar, S \& Gorail, A. K. 2013. Spatial Distribution Analysis of Groundwater Quality Index Using GIS: A Case Study of Ranchi Municipal Corporation (RMC) Area. A Scientific Journal of Geoinformatics and Geostatistics: an Overview, 1(2): 1-11 (doi:10.4172/2327-4581.1000105).

Langelier, W. F. 1936. The analytical control of anticorrosion water treatment. Journal of American Water Works Association, 28: 1500.

Larson, T.E \& Skold, R.V. 1958. Current research on corrosion and tuberculation of cast iron. Journal of American Water Works Association, 50(11): 1429-1432.

Mahmoud, S., Aliakbar, M \& Seyed Ali, S. 2012. Evaluation of Corrosion and Scale forming Potential of Water in Rural Water Supply Distribution Networks of Tabas, Iran. World Applied Sciences Journal, 17(11): 1484-1489. 
McDonald, J. 2006. Alkalinity and pH relationships, China Science and Technology Newsletter, 2. (Available online at http://www.veoliawatertech.com/crownsolutions/ resources documents, Water-/2/21951pp393-394.pdf).

McNeill, L. S \& Edwards, M. 2001. Review of iron pipe corrosion in drinking water distribution systems. Journal of American Water Works Association, 93(7): 88-100.

Minalah, B. 2007. Numerical Groundwater Flow Modeling of the Dire Dawa Area, Ph.D thesis, Addis Ababa University, School of graduate studies.

Narany, S., Ramli, F., Aris, Z., Sulaiman, A \& Fakharian, K. 2015. Groundwater irrigation quality mapping using geostatistical techniques in Amol-Babol plain, Iran. Arab Journal Geoscience, 8(2): 961-976.

Nguyen, C.K., Stone Edwards, K.R \& M. 2011. Chloride to Sulphate Mass Ratio: Practical Studies in Galvanic Corrosion of Lead Solder. Journal of Americal Water Works Associations, 103(1): 81-92 (doi: 10.1002/j.1551-8833.2011.tb11384.x).

Prisyazhniuk, A. V. 2007. Prognosticating scale-forming properties of water. Applied Thermal Engineering, 27(8): 1637-1641.

Puckorius, P \& Brooke, J. 1991. A new practical index for calcium carbonate scale prediction in cooling tower systems. Corrosion, 47(4): 280-284.

Reiber, S., Poulsom, S., Perry, S.A.L., Edwards, M., Patel, S \& Dodrill, D.M. 1997. A General Framework for Corrosion Control Based on Utility Experience. Project \#910. Journal of Americal Water Works Associations, Denver, CO.

Sajil Kumar, P. J. 2019. Assessment of corrosion and scaling potential of the groundwater in the Thanjavur district using hydrogeochemical analysis and spatial modeling techniques. SN Applied Sciences, 1: 395.

Salvato, J. A., Nemerow, N. L \& Agardy, F. J. 2003. Environmental Engineering. John Wiley \& Sons, Inc.

Sawyer, C.N \& McCarty, P.L. 1967. Chemistry for sanitary engineers, $2^{\text {nd }}$ edition, McGraw Hill, New York.

Seife Michael, B.1982. The Geology of the Dire Dawa Area (Exploratory Notes for Dire Dawa Map sheet NC 37 - 12).

Seifu, K., Addisu, H., Crane, E., Dochartaigh, Ó \& Bellwood-Howard, B.É. 2018. Africa Groundwater Atlas: Hydrogeology of Ethiopia, British Geological Survey. (Available online at http://earthwise.bgs.ac.uk/index.php/Hydrogeology_of_Ethiopia ) 
Singh, I.B \& Chakradhar, B. 1998. Effect of $\mathrm{pH}$ and hardness on the scale formation of mild steel in bicarbonate ion containing water. Corrosion and Its Controls, Volsiand II, 97: 1009-1012.

Singley, J. E., Beaudet, B. A \& Markey, P. H. 1984. Corrosion manual for internal corrosion of water distribution systems. Environmental science and engineering, Inc. Florida, $67 \mathrm{p}$.

Tamiru, A. 2006. Groundwater Occurrence in Ethiopia. Addis Ababa University, Addis Ababa: UNESCO.

Tavanpour, N \& Noshadi, M. 2016. Scale Formation and Corrosion of Drinking Water Pipes: A Case Study of Drinking Water Distribution System of Shiraz City. Modern Applied Science, 10(3): 166-177.

USGS. 2000. GW_Chart: A Program for Creating Specialized Graphs Used in Groundwater Studies.

Von Huben, H. 1995. Water treatment principles \& practices of water supply operations. American Water Works Association, pp. 36-72.

Webster, R \& Oliver, M.A. 2007. Geostatistics for Environmental Scientists. John Wiley \& Sons, Chichester.

WHO. 2003. Total Dissolved Solids in Drinking Water, WHO Guidelines for Drinking-water Quality, World Health Organization, Geneva.

WHO. 2011. Hardness in Drinking-water Background document for development of WHO Guidelines. World Health Organization, Geneva.

Zarif, F., Eslam, H \& Afrous, A. 2014. Spatial variation of corrosion and scale forming potential of groundwater using kriging (Dezfoul- Andimeshk Plain). Bulletin Environmental Pharmacology and Life Science, 4(1): 16-21. 
Appendix 1. The physiochemical analysis and corrosion indices of the Borehole of Dire Dawa City.

\begin{tabular}{|c|c|c|c|c|c|c|c|c|c|c|c|c|c|c|c|c|c|}
\hline Index & coor & Y-coor & $\mathbf{T}$ & TDS & pH & $\mathbf{C a}^{+}$ & $\mathrm{Mg}^{+}$ & $\mathrm{Cl}^{-}$ & $\mathrm{HCO}_{3}^{-}$ & $\mathrm{SO}_{4}^{-2}$ & TH & $\mathbf{A L}$ & LSI & RSI & AI & PSI & LRI \\
\hline BH-05 & 12378 & 1061804 & 22.3 & 532 & 7.4 & 116 & 28.7 & 83.6 & 373.3 & 18.46 & 306 & 409.6 & 0.4 & 6.6 & 12.4 & 5.9 & 0.3 \\
\hline BH-06 & 13870 & 1061350 & 25 & 946 & 7.6 & 200 & 20.9 & 150 & 378.2 & 50 & 310 & 587.2 & 0.7 & 6.2 & 12.8 & 5.6 & 0.5 \\
\hline BH-08 & 14520 & 1063426 & 26.4 & 598 & 7.3 & 128 & 34.1 & 67.1 & 441.6 & 47.5 & 362 & 462.1 & 0.4 & 6.5 & 12.4 & 5.6 & 0.3 \\
\hline BH-10 & 14020 & 1061049 & 27.3 & 834 & 7.3 & 152 & 30.2 & 80.6 & 373.3 & 39.56 & 306 & 505.7 & 0.4 & 6.5 & 12.4 & 5.7 & 0.3 \\
\hline BH-12 & 814172 & 1061499 & 26.5 & 1570 & 7.5 & 240 & 41.3 & 315 & 414.8 & 23.7 & 340 & 772.3 & 0.7 & 6.1 & 12.8 & 5.4 & 0.8 \\
\hline BH-13 & 814356 & 1064666 & 26.7 & 790 & 7.1 & 112 & 31.1 & 160.6 & 383 & 14.5 & 314 & 409.7 & 0.1 & 7.0 & 12.0 & 5.9 & 0.5 \\
\hline BH-14 & 14865 & 1063384 & 28 & 1245 & 7.7 & 240 & 44.7 & 215.6 & 353.8 & 221.5 & 290 & 786.5 & 1.0 & 5.8 & 12.9 & 5.3 & 1.2 \\
\hline BH-15 & 814941 & 1063539 & 25 & 1583 & 7.3 & 264 & 68.1 & 331.1 & 412.4 & 448.5 & 338 & 943.8 & 0.7 & 6.0 & 2.7 & 5.0 & 1.9 \\
\hline BH-02 & 816294 & 1059832 & 28 & 470 & 7.3 & 140 & 8.27 & 28.6 & 400.2 & 12.1 & 328 & 384.5 & 0.4 & 6.5 & 12.4 & 5.5 & 0.1 \\
\hline BH-21 & 11477 & 1071736 & 26.3 & 780 & 7.2 & 140.6 & 36.8 & 91.2 & 468.2 & 128.6 & 383.8 & 504.8 & 0.5 & 6.1 & 12.3 & 5.0 & 0.5 \\
\hline BH-43 & 812491 & 1063930 & 19.4 & 622 & 7.2 & 136 & 30.1 & 106 & 424.6 & 44.8 & 348 & 465.7 & 0.5 & 6.1 & 12.3 & 5.1 & 0.4 \\
\hline BH-48 & 810949 & 1067896 & 18.7 & 822 & 7.5 & 184.7 & 11.5 & 117 & 447.4 & 102.6 & 366.7 & 509.7 & 0.9 & 5.7 & 12.7 & 4.8 & 0.5 \\
\hline BH-50 & 5089 & 1067392 & 35 & 778 & 7.2 & 182.4 & 27.6 & 33.25 & 440.4 & 219.9 & 361 & 571 & 0.4 & 6.3 & 2.4 & 5.2 & 0.6 \\
\hline BH-53 & 813936 & 1061662 & 25.3 & 1092 & 8.1 & 214 & 29.5 & 166 & 322 & 56.7 & 263.9 & 657.9 & 1.1 & 5.8 & 13.2 & 5.8 & 0.7 \\
\hline BH-56 & 805241 & 1063341 & 23 & 598 & 7.3 & 128 & 34.1 & 67.1 & 441.6 & 47.5 & 362 & 462 & 0.4 & 6.5 & 12.3 & 5.5 & 0.3 \\
\hline BH-30 & 809629 & 1062713 & 28.4 & 910 & 7.3 & 144.4 & 57.5 & 79.8 & 573.4 & 180 & 600.6 & 470 & 0.7 & 6.2 & 12.3 & 5.0 & 1.8 \\
\hline BH-51 & 804918 & 1062924 & 28.3 & 1296 & 7.5 & 208 & 65.6 & 188.1 & 466 & 448.4 & 793.6 & 382 & 0.4 & 6.5 & 12.6 & 5.5 & 1.1 \\
\hline BH-77 & 804505 & 1059760 & 26.5 & 415 & 7.5 & 134 & 11.5 & 14.6 & 392.8 & 43.5 & 383 & 322 & 0.5 & 6.3 & 12.3 & 5.0 & 0.5 \\
\hline BH-1 & 816864 & 1067498 & 27.7 & 619 & 7.2 & 100 & 38 & 47 & 388 & 101 & 408.3 & 318 & 0.5 & 6.0 & 12.3 & 5.1 & 0.4 \\
\hline BH-04 & 816835 & 1067510 & 29 & 466 & 7.9 & 88 & 14.1 & 39.6 & 363.6 & 73.8 & 278.8 & 298 & 0.9 & 5.7 & 12.7 & 4.8 & 0.5 \\
\hline BH-60 & 813870 & 1061350 & 25 & 946 & 7.6 & 200 & 20.9 & 149.6 & 378.2 & 50.0 & 587.2 & 481.3 & 0.4 & 5.8 & 12.0 & 5.1 & 0.6 \\
\hline BH-53 & 813936 & 1061662 & 29.8 & 1092 & 8.1 & 214 & 29.5 & 165.9 & 322 & 56.7 & 657.9 & 539.3 & 1.1 & 5.2 & 13.2 & 5.9 & 0.7 \\
\hline BH-61 & 814020 & 1061049 & 26.3 & 834 & 7.3 & 152 & 30.2 & 80.6 & 373.3 & 39.6 & 505.7 & 414.5 & 0.4 & 6.5 & 12.3 & 5.4 & 0.3 \\
\hline BH-57 & 814172 & 1061499 & 21.8 & 1570 & 7.5 & 240 & 41.3 & 314.6 & 414.8 & 23.7 & 772.3 & 633 & 0.1 & 6.6 & 12.4 & 6.2 & 0.8 \\
\hline
\end{tabular}




\begin{tabular}{|c|c|c|c|c|c|c|c|c|c|c|c|c|c|c|c|c|c|}
\hline BH-67 & 814356 & 1064666 & 19 & 790 & 7.1 & 112 & 31.1 & 160.6 & 383.1 & 14.5 & 409.7 & 335.8 & 0.5 & 7.0 & 12.0 & 5.9 & 0.5 \\
\hline \begin{tabular}{|l|} 
CBH-12 \\
\end{tabular} & 812527 & 1063543 & 29.5 & 892 & 7 & 164 & 52 & 194 & 353 & 150 & 289.3 & 626.7 & 0.1 & 6.8 & 12.1 & 5.6 & 0.9 \\
\hline$\overline{\text { DBh-13 }}$ & 816872 & 1061784 & 36 & 1708 & 7 & 238 & 68 & 335 & 438 & 349 & 359 & 878.3 & 0.6 & 5.9 & 12.4 & 4.6 & 1.6 \\
\hline FBh-12 & 814520 & 1063426 & 23 & 1153 & 7.1 & 183 & 48 & 125 & 344 & 95 & 282 & 657.5 & 0.3 & 6.6 & 12.2 & 5.6 & 0.6 \\
\hline HBH-1 & 814520 & 1061049 & 28 & 941 & 6.8 & 123 & 37 & 83 & 520 & 40 & 426.2 & 461.7 & -0.1 & 7.1 & 11.8 & 5.6 & 0.3 \\
\hline MBh-1 & 811769 & 1063611 & 19 & 647.4 & 7.2 & 110 & 39 & 57 & 443 & 64 & 363.1 & 437.5 & 0.2 & 6.7 & 12.2 & 5.6 & 0.3 \\
\hline MBh-10 & 808534 & 1064055 & 24.2 & 860.9 & 7.9 & 132 & 50 & 131 & 437 & 87 & 358.2 & 538.3 & 1.0 & 5.9 & 12.9 & 5.5 & 0.5 \\
\hline TBh-3 & 816080 & 1062886 & 26 & 1649 & 7.1 & 240 & 65 & 354 & 403 & 250 & 330.3 & 870.8 & 0.4 & 6.3 & 12.4 & 5.2 & 1.5 \\
\hline PW-13 & 812573 & 1062411 & 35 & 734 & 6.9 & 177.6 & 37.4 & 97.8 & 488 & 80.3 & 400 & 600 & 0.5 & 6.0 & 12.2 & 4.5 & 0.4 \\
\hline PW-2 & 805167 & 1063299 & 35 & 2620 & 6.7 & 596.8 & 122 & 23.5 & 297.7 & 1611 & 244 & 2000 & 0.2 & 6.5 & 12.1 & 4.9 & 5.5 \\
\hline PW-30 & 813111 & 106 & 19.7 & 1712 & 6.7 & 352 & 5.7 & 88.6 & 366 & 733.1 & 300 & 904 & 0.3 & 6.1 & 12.1 & 4.6 & 2.3 \\
\hline PW-4 & 812527 & 1063543 & 22 & 923 & 6.8 & 137.6 & 37.4 & 81.3 & 478.2 & 74.5 & 392 & 500 & 0.2 & 6.4 & 12.0 & 4.9 & 0.3 \\
\hline SBh-1 & 812491 & 1063930 & 18 & 722 & 7.1 & 133 & 33 & 88 & 427 & 54 & 350 & 470 & 0.4 & 6.2 & 12.2 & 5.1 & 0.3 \\
\hline SBh-9 & 813111 & 1063263 & 20.9 & 1101 & 7.1 & 171 & 43 & 162 & 372 & 81 & 304.9 & 606.7 & 0.3 & 6.6 & 12.2 & 5.5 & 0.7 \\
\hline SnBh-1 & 814072 & 1065654 & 25.5 & 802.4 & 7.3 & 118 & 48 & 101 & 462 & 99 & 378.7 & 495 & 0.3 & 6.7 & 12.4 & 5.7 & 0.4 \\
\hline SnBh-2 & 815062 & 1065559 & 35 & 1039 & 6.8 & 302.4 & 67.9 & 71.1 & 463.6 & 765 & 1039 & 380 & 0.0 & 7.0 & 12.0 & 5.9 & 0.5 \\
\hline TW1 & 808291 & 1066600 & 28 & 1600 & 6.8 & 169 & 42 & 71.1 & 580.7 & 89.2 & 599.9 & 476 & 0.5 & 5.7 & 12.3 & 4.2 & 1.8 \\
\hline PW1 & 805800 & 1063087 & 31 & 712 & 6.8 & 195.8 & 50.7 & 88.6 & 580.7 & 117 & 700.8 & 476 & 0.5 & 6.0 & 12.1 & 4.5 & 0.4 \\
\hline PW11 & 808515 & 1064885 & 29 & 1114 & 6.8 & 302.4 & 67.9 & 71.1 & 463.6 & 765 & 1039 & 380 & 0.5 & 5.7 & 12.3 & 4.2 & 1.8 \\
\hline PW14 & 811995 & 1063764 & 33 & 850 & 6.9 & 167 & 38 & 70.2 & 492.8 & 112 & 575.9 & 404 & 0.4 & 6.1 & 12.2 & 4.4 & 0.3 \\
\hline PW16 & 812986 & 1062405 & 35 & 680 & 7.2 & 288 & 144 & 59.7 & 370.8 & 1086 & 1320 & 304 & 0.4 & 6.0 & 12.1 & 4.5 & 0.4 \\
\hline PW17 & 812384 & 1064409 & 29 & 1892 & 6.7 & 358.4 & 140 & 65.1 & 341.6 & 1300 & 1480 & 280 & 0.7 & 5.8 & 12.5 & 4.7 & 3.1 \\
\hline PW18 & 815570 & 1064147 & 31 & 2148 & 6.7 & 568 & 91.2 & 14.5 & 302.5 & 1809 & 1800 & 248 & 0.1 & 6.5 & 12.1 & 5.1 & 4.0 \\
\hline PW22 & 814254 & 1061551 & 25 & 2800 & 7.5 & 112 & 12 & 46.6 & 536.8 & 68.8 & 330 & 440 & 0.3 & 6.1 & 12.2 & 4.8 & 6.0 \\
\hline PW28 & 812180 & 1061149 & 26 & 1390 & 6.8 & 448 & 46.1 & 55.5 & 370.8 & 1133 & 1312 & 304 & 0.7 & 6.0 & 12.5 & 5.0 & 1.0 \\
\hline T-2 & 814034 & 1065326 & 26 & 1968 & 6.9 & 427.2 & 50.8 & 53.7 & 375.7 & 1087 & 1280 & 308 & 0.4 & 6.1 & 12.4 & 4.7 & 3.0 \\
\hline
\end{tabular}




\begin{tabular}{|l|l|l|l|l|l|l|l|l|l|l|l|l|l|l|l|l|l|}
\hline T-3 & 813410 & 1065622 & 29 & 1900 & 6.9 & 160 & 24 & 90.3 & 434.3 & 180 & 480 & 356 & 0.6 & 5.6 & 12.3 & 4.2 & 3.2 \\
\hline $\mathbf{B - 1}$ & 809650 & 1066200 & 28 & 838 & 6.6 & 168 & 36.5 & 55.4 & 451 & 190 & 572 & 370 & 0.5 & 6.6 & 13.4 & 4.9 & 0.4 \\
\hline $\mathbf{B - 5}$ & 807900 & 1067200 & 31 & 804 & 7.5 & 157.6 & 11.8 & 53.2 & 507.7 & 145 & 432.6 & 416 & 0.4 & 6.7 & 13.4 & 4.8 & 0.3 \\
\hline $\mathbf{B - 6}$ & 808500 & 1066000 & 33 & 756 & 6.9 & 320 & 28.8 & 43.7 & 329.4 & 855 & 920 & 270 & 0.5 & 6.6 & 13.3 & 5.0 & 0.4 \\
\hline $\mathbf{B - 7}$ & 807850 & 1065700 & 32 & 1472 & 7.2 & 236.7 & 20.3 & 48.4 & 418.5 & 500 & 676.3 & 343 & 0.7 & 5.9 & 12.3 & 4.9 & 0.9 \\
\hline
\end{tabular}

Measuring unit of each parameter - T( $\left.{ }^{\circ} \mathrm{C}\right)$-Temperature, TDS (mg/l), $\mathrm{Ca}^{+}(\mathrm{mg} / \mathrm{l}), \mathrm{Mg}^{+}(\mathrm{mg} / \mathrm{l}), \mathrm{Cl}^{-}(\mathrm{mg} / \mathrm{l}), \mathrm{HCO}_{3}{ }^{-}(\mathrm{mg} / \mathrm{l}) \mathrm{SO}_{4}^{-2}(\mathrm{mg} / \mathrm{l}), \mathrm{Na}{ }^{+}(\mathrm{mg} / \mathrm{l})$,

Total Hardness (TH) (mg/l as $\left.\mathrm{CaCO}_{3}\right)$ and Total Alkaliniy (TA) $\left(\mathrm{mg} / \mathrm{l}\right.$ as $\left.\mathrm{CaCO}_{3}\right)$

LSI: Langlier Saturation Index, RSI: Ryznar Saturation Index, AI: Aggressive Index; LSI: Larson Skold Index, PSI: Pockorous Saturation Index;

Appendix 2. The physiochemical analysis and corrosion indices of Dug wells of Dire Dawa City.

\begin{tabular}{|c|c|c|c|c|c|c|c|c|c|c|c|c|c|c|c|c|c|}
\hline Index & -coor & -coor & $\mathbf{T}$ & TDS & pH & $\mathrm{Ca}^{+}$ & $\mathbf{M g}^{+}$ & $\mathrm{Cl}^{-}$ & $\mathrm{HCO}_{3}{ }^{-}$ & $\mathrm{SO}_{4}{ }^{-2}$ & TH & $\mathbf{A L}$ & LSI & RSI & $\overline{\text { AI }}$ & PSI & LRI \\
\hline $\mathrm{N}-1$ & 009 & 61596 & 19 & 135 & 6.8 & 168 & 55 & 97 & 08 & 97 & 16.4 & 649.2 & 0.0 & 6.9 & 2.0 & 5.3 & 0.6 \\
\hline-21 & 5113 & 059868 & 12.6 & 26 & 7.6 & 120 & 27 & 51.6 & 297.7 & 147.7 & 244 & 416 & -0.1 & 6.9 & 11.9 & 5.3 & 0.5 \\
\hline DW-23 & 816238 & 1066909 & 0.5 & 884 & 6.7 & 184 & 19.5 & 60.6 & 31.8 & 5.4 & 54 & 541 & 0.6 & 6.9 & 2.5 & 6.8 & 0.1 \\
\hline & & & 27 & & 7.9 & & & & & & & & 0. & & 4 & 1 & 0.6 \\
\hline-12 & 6000 & 1067040 & 25 & 1416 & 7.4 & 144 & 75.4 & 249 & 463.6 & 448.4 & 380 & 674 & 0.6 & 6.3 & 12.5 & 5.4 & 1.5 \\
\hline W-19 & 6316 & 1064129 & 25 & 670 & 7.3 & 168 & 24.3 & 83.6 & 461.2 & 42.24 & 378 & 521.3 & 0.6 & 6.2 & 12.5 & 5.2 & 0.3 \\
\hline DW-30 & 811769 & 1063611 & 24.6 & 989 & 7.1 & 183 & 18 & 91.2 & 475.8 & 65.9 & 390 & 532.5 & 0.6 & 6.0 & 12.4 & 4.8 & 0.3 \\
\hline W-32 & 814113 & 1056268 & 23.5 & 884 & 6.7 & 184 & 19.4 & 160.6 & 431.9 & 55.4 & 541.1 & 354 & 0.5 & 6.0 & 12.1 & 4.5 & 0.4 \\
\hline 1 & 6574 & 8 & 36 & 526 & 7.6 & 120 & 27.8 & 61.6 & 297.7 & 147.7 & 416.1 & 244 & 0.4 & 6.2 & 12.2 & 5.1 & 0.3 \\
\hline W-33 & 814113 & 1056268 & 26 & 884 & 6.7 & 184 & 19.5 & 160.6 & 431.9 & 55.4 & 541.1 & 35 & 0.3 & 6. & 12.2 & 5.5 & 0.7 \\
\hline W-34 & 816574 & 1067528 & 25 & 526 & 7.6 & 120 & 27.8 & 61.6 & 297.7 & 147.7 & 416.1 & 244 & 0.7 & 5.8 & 12.5 & 4.7 & 0.3 \\
\hline
\end{tabular}

Measuring unit of each parameter $-\mathrm{T}\left({ }^{\circ} \mathrm{C}\right)$-Temperature, TDS $(\mathrm{mg} / \mathrm{l}), \mathrm{Ca}^{+}(\mathrm{mg} / \mathrm{l}), \mathrm{Mg}^{+}(\mathrm{mg} / \mathrm{l}), \mathrm{Cl}^{-}(\mathrm{mg} / \mathrm{l}), \mathrm{HCO}_{3}{ }^{-}\left(\mathrm{mg}^{-1}\right) \mathrm{SO}_{4}^{-2}(\mathrm{mg} / \mathrm{l}), \mathrm{Na}^{+}(\mathrm{mg} / \mathrm{l})$, Total Hardness (TH) (mg/l as $\left.\mathrm{CaCO}_{3}\right)$ and Total Alkalinity (TA) (mg/l as $\left.\mathrm{CaCO}_{3}\right)$

LSI : Langlier Saturation Index, RSI: Ryznar Saturation Index, AI: Aggressive Index; LSI: Larson Skold Index, PSI: Pockorous Saturation Index; 
Appendix 3. The physiochemical analysis and corrosion indices of Dug wells of Dire Dawa City.

\begin{tabular}{|c|c|c|c|c|c|c|c|c|c|c|c|c|c|c|c|c|c|}
\hline Index & $X$-coor & $Y$-coor & $T$ & $T D S$ & $p H$ & $\mathrm{Ca}^{+}$ & $\mathrm{Mg}^{+}$ & $\mathrm{Cl}^{-}$ & $\mathrm{HCO}_{3}^{-}$ & $\mathrm{SO}_{4}^{-2}$ & $T H$ & $A L$ & $L S I$ & $R S I$ & $A I$ & $P S I$ & $L R I$ \\
\hline MSP-3 & 815730 & 1061000 & 19 & 514.7 & 7.3 & 111 & 27 & 17 & 445 & 19 & 364.8 & 390 & 0.3 & 6.7 & 12.3 & 5.7 & 0.1 \\
\hline SP-1 & 807621 & 1059771 & 26 & 1268 & 7.4 & 184 & 60.8 & 281.6 & 427 & 290.2 & 350 & 713.3 & 0.5 & 6.3 & 12.6 & 5.5 & 1.3 \\
\hline Sp12 & 816904 & 1073154 & 37 & 688 & 7.7 & 159.6 & 31.3 & 32.3 & 299 & 263.7 & 245 & 529.3 & 0.8 & 6.1 & 12.7 & 5.4 & 1.0 \\
\hline SP-14 & 812255 & 1061280 & 25.3 & 526 & 7.6 & 132 & 17 & 94.6 & 356.2 & 7.9 & 292 & 400.9 & 0.6 & 6.4 & 12.6 & 5.8 & 0.3 \\
\hline SP-19 & 814595 & 1059950 & 25.7 & 680 & 7.4 & 152 & 9.7 & 105.6 & 390.4 & 5.27 & 320 & 420.5 & 0.4 & 6.5 & 12.5 & 5.7 & 0.3 \\
\hline SP-21 & 816219 & 1061625 & 20.3 & 570 & 7.4 & 140 & 24.3 & 56.1 & 507.5 & 15.8 & 416 & 451.3 & 0.6 & 6.2 & 12.6 & 5.2 & 0.1 \\
\hline SP-25 & 813438 & 1059985 & 24.8 & 570 & 7.4 & 140 & 24.3 & 56.1 & 507.5 & 15.8 & 416 & 451.3 & 0.5 & 6.3 & 12.6 & 5.4 & 0.1 \\
\hline SP-26 & 816850 & 1059880 & 40 & 544 & 7.6 & 128 & 26.8 & 94.6 & 295.2 & 50.1 & 242 & 431.5 & 0.4 & 6.7 & 12.5 & 6.3 & 0.5 \\
\hline SP-3 & 815449 & 1059700 & 25 & 408 & 7.1 & 200 & 4.8 & 34.1 & 231.8 & 5.27 & 190 & 520.3 & 0.0 & 7.0 & 12.1 & 6.3 & 0.2 \\
\hline SP-5 & 815794 & 1059800 & 24 & 270 & 7.3 & 64 & 4.8 & 34.1 & 187.9 & 18.2 & 154 & 180.3 & -0.4 & 8.1 & 11.7 & 7.6 & 0.3 \\
\hline SP-7 & 816000 & 1059801 & 37 & 458 & 7.5 & 144 & 17 & 28.6 & 446.5 & 15.8 & 366 & 430.9 & 0.6 & 6.3 & 12.6 & 5.5 & 0.1 \\
\hline SP-8 & 812000 & 1072000 & 24.8 & 528 & 7.7 & 129.2 & 16.1 & 24.7 & 419.7 & 78.3 & 344 & 390.1 & 0.7 & 6.3 & 12.8 & 5.6 & 0.3 \\
\hline DSP_1 & 814232 & 1060663 & 22.5 & 1476 & 7.1 & 160 & 70 & 262 & 449 & 234 & 368 & 691.7 & 0.3 & 6.6 & 12.3 & 5.4 & 1.1 \\
\hline FSP-5 & 813592 & 1060342 & 25.2 & 720 & 7 & 128 & 23 & 91 & 415 & 40 & 3402 & 415.8 & 0.1 & 6.9 & 12.0 & 5.7 & 0.3 \\
\hline LSP-6 & 806574 & 1063754 & 28.6 & 786.7 & 7 & 143 & 30 & 120 & 437 & 63 & 358.2 & 482.5 & -0.2 & 7.1 & 11.8 & 5.5 & 0.4 \\
\hline
\end{tabular}

Measuring unit of each parameter $-\mathrm{T}\left({ }^{\circ} \mathrm{C}\right)$-Temperature, TDS $(\mathrm{mg} / \mathrm{l}), \mathrm{Ca}^{+}(\mathrm{mg} / \mathrm{l}), \mathrm{Mg}^{+}(\mathrm{mg} / \mathrm{l}), \mathrm{Cl}^{-}(\mathrm{mg} / \mathrm{l}), \mathrm{HCO}_{3}{ }^{-}(\mathrm{mg} / \mathrm{l}) \mathrm{SO}_{4}^{-2}(\mathrm{mg} / \mathrm{l}), \mathrm{Na}^{+}(\mathrm{mg} / \mathrm{l})$, Total Hardness (TH) (mg/l as $\left.\mathrm{CaCO}_{3}\right)$ and Total Alkaliniy (TA) (mg/l as $\left.\mathrm{CaCO}_{3}\right)$

LSI : Langlier Saturation Index, RSI: Ryznar Saturation Index, AI: Aggressive Index; LSI: Larson Skold Index, PSI: Pockorous Saturation Index; 